\title{
The Problems of Agriculture and Rural Areas in the Process of European Integration
}

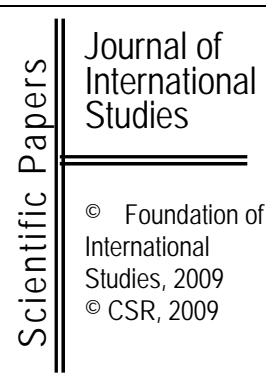

\author{
Barbara Chmielewska \\ Institute of Agricultural and Food Economics - \\ National Research Institute, \\ 00-002 Warsaw Świetokryyska 20, St., Poland \\ e-mail: chmielewska@ierigz.waw.pl
}

\begin{abstract}
The CAP instruments have played a positive role in creating changes in the agricultural sector and in rural areas, although they have not attained many of the objectives for which they were designed. The agriculture (and mostly the semi-subsistence farms) and rural areas have little chances of development without the financial support of the EU, especially in poorer countries.

Therefore, the political rank attributed to the problems of the development of farming and rural areas in the EU policy is important. In the present article, these issues are presented on the basis of the example of the Mazowieckie voivodeship. The first stage of implementation of the EU agriculture and rural development support programmes in Poland has not been fully successful. First of all, the development disproportions in the region have not diminished, which resulted mostly from the amount of funding, not sufficient for the existing needs, and a too short period of implementation.

The most visible improvement in the rural areas occurred in technical infrastructure equipment, mostly for transport purposes. A slight improvement in the agrarian structure of farming also took place. Currently, the beneficial solution for all the EU countries is a multifunctional development of agriculture which implies the multifunctionality of rural areas. Only a multifunctional development of agriculture and rural areas can assure sustainable development.
\end{abstract} Submitted: January, 2009 1st revision: May, 2009

Keywords: agriculture, rural areas, EU funds, Mazowieckie voivodeship

Accepted: June, 2009

JEL classification: Q1, P25, R51, P1

\section{Introduction}

The basic principle of the EU policy is to ensure the Member States a sustainable economic and social progress by supporting their comprehensive and harmonious development and especially by alleviating the differences in the level of regional development. The European Union is a community of countries of different histories of 
membership with regions of different economic development levels. It can be observed mostly in the size of GDP per inhabitant, in the level of unemployment, in the employment structure and on the basis of income and life standard of the population, as well as in the technical, communications, transport and social infrastructure. The integration processes contribute to the diminishing of the gap between regions, but they may also widen the gap. The problem is especially visible in agricultural sector and rural areas.

Polish farming and rural areas, compared to the more economically developed countries (EU-15), are characterised by much lower production and economic indicators, resulting mainly from a fragmented agrarian structure, excessive employment in the sector, lower labour effectiveness, lower land productivity and infrastructural underinvestment in rural areas. The indicators showing the presence of the infrastructure for water supply and sewage, as well as for gas and transport are low.

All this resulted in the situation where our agriculture and rural areas were confronted with a huge task of diminishing the gap separating them from the agriculture and rural areas development level of the older Member States. Not many farms were competitive on the EU market.

The basic task was restructuring, mostly of the agrarian structure, as well as achieving modernisation and biotechnological progress in agricultural production.

The implementation of the Common Agricultural Policy was to improve the situation in Polish agricultural and food sector (similarly as in the other "new" Member States). Unfortunately, the accession in 2004 coincided with the CAP reform, changing the rules of support to farming. In general, the CAP instruments have played a positive role in creating changes in the agricultural sector and in rural areas, although they have not attained many of the objectives for which they were designed.

The agriculture (and mostly the semi-subsistence farms) and rural areas have little chances of development without the financial support of the EU, especially in poorer countries. Therefore, the political rank attributed to the problems of the development of farming and rural areas in the EU policy is important. The said issues are presented on the example of the Mazowieckie voivodeship (Chmielewska 2008).

\section{The EU instruments of support to agriculture and rural areas}

The basic EU instruments of support to agriculture and rural areas in Poland were the pre-accession programmes (ISPA, SAPARD, Phare, Interreg) and the following schemes after the accession: direct payments for the rural areas, the Rural Development Plan (RDP 20042006 and RDP 2007-2013); the Rural Areas Activation Programme, the SOP "Restructuring and modernisation of the food sector and the development of rural areas, 2004-2006", support to fruit and vegetable markets.

The basic institutions established to service the EU programmes are the Agency for the Restructuring and Modernisation of Agriculture (ARMA) and the Agricultural Markets Agency (AMA).

\subsection{The tasks carried out by ARMA in the Mazowieckie voivodeship}

Within the SAPARD programme 5,138 applications were submitted in the Mazowieckie voivodeship for four measures, 4,336 contracts were signed for the total amount of 584.5 million PLN (as at 14.06.2005). The largest number of applications was submitted for the measure: "Investments in agricultural holdings" (3,718 applications, 3,423 contracts were signed for the total amount of 152.2 million PLN).

The measures which ranked second and third were: "The development and 
improvement of infrastructure in rural areas" (650 applications, 453 contracts were signed for the total amount of 187 million PLN); "Diversification of economic activity in rural areas" (554 applications were submitted, 313 contracts were signed for the total amount of 32.4 million PLN).

The measure with the least popularity was: "Improvement of the processing and marketing of agricultural and fish products" (216 applications were submitted, 147 contracts were signed for the total amount of 212.5 million PLN). (Annual Report from the implementation of the SAPARD Programme ... 2005, Voivodeship Contract ... 2005).

In Mazowieckie voivodeship noted the largest number of projects implemented on the basis of applications under the SAPARD Programme (14.3\% of the total number of projects implemented on the basis of these applications in the country); but in terms of the share of projects which were implemented $(64.1 \%)$ in the total number of applications approved for financing, Mazowieckie ranked third behind the Lubelskie (69.5\%) and Kujawsko-Pomorskie (67.5\%) voivodeships.

The programme complementary to the SAPARD Programme was the Rural Areas Activation Programme. The programme covered the inhabitants of rural areas and small towns (not more than 15 thousand of inhabitants). The total budget of the Programme for the country was 297.9 million EUR, including the amount of 3,565 thousand EUR assigned for Mazovia, earmarked for the co-funding of the investment in water supply and sewage treatment systems, the solid waste management and local and district roads.

Within the Rural Areas Activation Programme in the Mazowieckie voivodeship the following subcomponents were implemented: B2, B3 and C. Under the subcomponent B2 "Education", the number of 295 projects was implemented, of which 192 renovation projects and 103 projects equipping school facilities together in 10 poviats and 145 gminas. In B3 "Institutional capacity" a total number of 548 persons from 67 gminas and 14 poviats were trained in the principles of modern management and 471 persons in counteracting unemployment. In component C "Rural infrastructure" 59 infrastructure projects received financing including: 4 sewage systems, 2 landfills, 17 water supply systems, 36 road projects (26 roads in gminas and 16 poviat roads).

Trainings for the councillors and the employees of the local government units in the amount of 7,281 person-days were assured, as well as the additional funds for carrying out of the B2 subcomponent: "Education" in the amount of 1,487 thousand EUR. In total, the Mazowieckie voivodeship received 5,052 thousand EUR for the implementation of tasks under the Rural Areas Activation Programme, which constituted 1.7\% of the national budget of this programme. The programme was implemented until 30.06.2005. (the Rural Areas Activation Programme .... 2005).

The basic instrument of support to farming from the EU funds were payments to rural areas. Table 1 presents data concerning the implementation of direct payments in Mazowieckie voivodeship.

In Mazowieckie voivodeship, the largest number of applications for area payments was submitted (218.2 thousand in 2006). This results mainly from the highest number of agricultural holdings per voivodeship, because the share of submitted applications per total number of holdings in Mazowieckie voivodeship was not the highest in the country and shaped at the level of $76-81 \%$. 
Table 1. The implementation of direct payments in Mazowieckie voivodeship in 2004-2006.

\begin{tabular}{|c|c|c|c|c|c|c|c|c|}
\hline \multirow[t]{3}{*}{ Years } & \multicolumn{6}{|c|}{ Number of applications } & \multicolumn{2}{|c|}{$\begin{array}{l}\text { The amount of } \\
\text { executed } \\
\text { payments }\end{array}$} \\
\hline & \multicolumn{2}{|c|}{ submitted } & \multicolumn{2}{|c|}{$\begin{array}{l}\text { implemented } \\
\text { projects }\end{array}$} & \multicolumn{2}{|c|}{$\begin{array}{c}\text { Projects } \\
\text { implemented } \\
\text { in } \% \text { as the share of: }\end{array}$} & \multirow{2}{*}{$\begin{array}{l}\text { in } \\
\text { millio } \\
\text { ns of } \\
\text { PLN }\end{array}$} & \multirow{2}{*}{$\begin{array}{c}\% \\
\text { of the } \\
\text { nation } \\
\text { al } \\
\text { amoun } \\
\mathrm{t}\end{array}$} \\
\hline & $\begin{array}{l}\text { in } \\
\text { number } \\
\mathrm{s}\end{array}$ & $\begin{array}{l}\text { in } \% \text { in } \\
\text { total in } \\
\text { the } \\
\text { country }\end{array}$ & $\begin{array}{c}\text { in } \\
\text { number } \\
\mathrm{s}\end{array}$ & $\begin{array}{l}\text { in } \% \text { in } \\
\text { total in } \\
\text { the } \\
\text { country }\end{array}$ & $\begin{array}{l}\text { submitt } \\
\text { ed } \\
\text { applicat } \\
\text { ions }\end{array}$ & $\begin{array}{l}\text { number } \\
\text { of } \\
\text { holdings } \\
* *\end{array}$ & & \\
\hline \multicolumn{9}{|c|}{ Direct payments } \\
\hline 2004 & 207,851 & 14.8 & 205,325 & 14.9 & 98.8 & 75.9 & 824.9 & 13.0 \\
\hline 2005 & 223,849 & 15.1 & 219,829 & 15.0 & 98.2 & 81.3 & 882.6 & 13.2 \\
\hline 2006 & 222,413 & 15.1 & 218,192 & 15.1 & 98.1 & 80.7 & $\begin{array}{c}1,022 . \\
8\end{array}$ & 13.1 \\
\hline $2007^{\mathrm{a}}$ & 219,958 & 15.1 & $\mathrm{X}$ & $\mathrm{X}$ & $\mathrm{x}$ & $\mathrm{x}$ & $\mathrm{x}$ & $\mathrm{x}$ \\
\hline \multicolumn{9}{|c|}{ Payments for the plantations of willow or multiflora rose } \\
\hline 2005 & 55 & 9.5 & 35 & 16.7 & 63.6 & & $120.3^{b}$ & 15.2 \\
\hline 2006 & 54 & 8.6 & 54 & 11.0 & 100.0 & & $185.7^{b}$ & 11.0 \\
\hline \multicolumn{9}{|c|}{ Payments for energy crops in 2007} \\
\hline 2007 & 330 & 3.5 & $\mathrm{x}$ & $\mathrm{x}$ & $\mathrm{x}$ & $\mathrm{x}$ & $\mathrm{x}$ & $\mathrm{x}$ \\
\hline \multicolumn{9}{|c|}{ Separate payment for sugar } \\
\hline 2006 & 6,189 & 10.1 & $\mathrm{x}$ & $\mathrm{x}$ & $\mathrm{x}$ & $\mathrm{x}$ & $\mathrm{x}$ & $\mathrm{x}$ \\
\hline
\end{tabular}

* Implemented projects/submitted applications. ** The ratio was calculated per total number of agricultural holdings larger than 1 ha of arable land in Mazowieckie voivodeship in 2005. ${ }^{\text {a. }}$ As at 11.07.2007. ${ }^{\mathrm{b} .}$ In thousand PLN.

Source: Agency for the Restructuring and Modernisation of Agriculture - three years after the accession. ARMA, Warsaw 2007.

In Mazowieckie voivodeship:

- 6,440 farmers submitted applications for co-financing of measures under the SOP "Restructuring and modernisation of the food sector and the development of rural areas, 20042006", the amount of requested support was over 676.2 million PLN (as at 07.07.2005).

- under the Rural Development Plan (RDP 2004-2006) the majority of farmers received grants for semi-subsistence farms (15,269 holdings) and for adjusting agricultural holdings to EU standards $(11,525)$. Early retirement was granted to 6764 holdings (the average amount of benefits was approx. 1400 PLN). The holdings located on less favoured areas submitted 113.5 thousand applications and 3,820 applications were submitted for the co-financing of agrienvironmental projects and the improvement of animal welfare (from 01.09.2004 to 31.12.2005) (as at 2005, ARMA - two years after the accession 2006). 


\section{EU funds for the Mazowieckie voivodeship earmarked for the development of agriculture and rural areas for the years 2007-2015}

Within the framework of the National Cohesion Strategy for 2007-2013 the Mazowieckie voivodeship will receive for the investment carried out in the region around 2,602.52 million EUR of EU funds. The amount includes the allocation for the Regional Operational Programme (1,881,50 million EUR) and the regional component of OP Human Capital (771.02 million EUR). For comparison in the years 2004-2006, under the Integrated Regional Operational Programme the allocation for the Mazowieckie voivodeship amounted to 299.84 million EUR.

Within the framework of the Rural Development Operational Programme, according to the allocation for selected measures proposed by the Ministry of Agriculture and Rural Development (, the Mazowieckie voivodeship will receive approx. 676.18 million EUR from the European Agricultural Fund for Rural Development (EAFRD). This amount may be raised with the funds earmarked for the management of agricultural water resources (website of the MARD 2007).

\section{Making use of the development capacity of the region}

\subsection{The level of absorption of EU funds}

The Mazowieckie voivodeship was one of the most active in the absorption of EU funds. The large majority of farms benefited from the EU funds, although not all possibilities were used.

$\Rightarrow$ The total of EU funds earmarked for the development and modernisation of agriculture was not used, e.g. under the SAPARD Programme.

$\Rightarrow$ The highest level of absorption of EU funds was in the field of rural areas infrastructure development (road infrastructure, sewage systems, water supply, water treatment stations, sewage treatment plants, the small water retention systems, renovation and modernisation of school buildings, equipping the schools especially in IT equipment).

$\Rightarrow$ The large majority of farmers benefited from direct payments.

$\Rightarrow$ Introducing early retirement scheme was not of much importance for the change of agrarian structure, nor for the increase of the revenue level of farming families (in the total number of 23 thousand holdings managed by persons aged 55 and older, the applications for early retirement were registered by slightly over 5 thousand of the managers of holdings). Many farmers did not apply for early retirement because of the barrier of legal regulations and strict rules defining the rights to obtain the benefit, which for many was difficult to overcome.

$\Rightarrow$ The expected results for the creation of producer groups were not attained, which resulted in the small use of EU funds by agriculture and horticulture producers for the creation or modernisation of the storage and distribution base within producer groups and organisations.

$\Rightarrow$ In the Mazowieckie voivodeship, the largest number of holdings benefited from the EU funds for the RDP 2004-2006 implementation and many measures noted more applications than the established limit.

\section{Conclusions}

The first stage of implementation of the EU agriculture and rural development support programmes has not been fully successful. Firstly, the development disproportions in the region have not diminished, which resulted mostly from the amount of funding, not sufficient for the existing needs, and too short period of implementation. 
The most visible improvement occurred in the field of technical infrastructure, mainly transport infrastructure, and in environmental protection, health care and education.

A slight improvement in the agrarian structure of farming was achieved. The average holding in Mazovia increased by 0.7 ha; the share of small-size farms diminished. The interest in organic farming grew larger.

The sector of agriculture should be supported and so should be rural areas, as the place of work and the source of income of many families which do not have better ways of earning their living. Moreover, the agriculture is the basic source of non-commercialised production of food and the guarantee of vitality of rural areas. All the more so that the experiences of the developed EU countries show that the high level of concentration of land and technisation of agricultural production leads to the depopulation of rural areas and the loss of their natural characteristics, the lowering of the quality of food products and a threat to sustainable development.

Currently, the beneficial common solution for all the EU countries is the multifunctional development of agriculture, as only this model may ensure sustainable development. The multifunctionality of agriculture, in turn, leads to the multifunctionality of rural areas. There is the mutual connection, because in highly developed countries (with the industrial model of farming), restricting the excessive concentration of agriculture will contribute to the return of the inhabitants of urban areas to rural areas. Whereas in the economically backward areas it will stimulate the need to expand the services and social infrastructure.

\section{REFERENCES:}

1. Agency for the Restructuring and Modernisation of Agriculture (ARMA) - two years after the accession. ARMA, Warsaw 2006.

2. Agency for the Restructuring and Modernisation of Agriculture - three years after the accession. ARMA, Warsaw 2007.

3. Chmielewska B.,: Agriculture and rural areas in Mazowieckie voivodeship in terms of the local development strategies and EU support. Chapter in the publication: Sustainable local development, EU support instruments for agriculture and rural areas in 2007-2013. Scientific edition: prof. Paweł Mickiewicz, Ph.D., Wojciech Gotkiewicz, Ph.D., vol. 2, p. 14-23. Published by: the Scientific Association at the Economy and Market Institute, University of Agriculture in Szczecin, Faculty of Economics and Organisation of Food Economy, Szczecin.

4. The Voivodeship Contract for the Mazowieckie Voivodeship for the years 2005-2006. Warsaw 2005.

5. Rural Areas Activation Programme. Published by: Foundation of Assistance Programmes for Agriculture (FAPA). Warsaw 2005.

6. The annual report from the implementation of the SAPARD Programme in Poland (for the period: 1.01.2004-31.12.2004). Article 8, Chapter B of the Multiannual Financial Agreement. The Ministry of Agriculture and Rural Development, Warsaw, 2005.

7. Integrated Regional Operational Programme 2004-2006. Journal of Laws, No. 166, item 1745. Annex to the ordinance of the Minister of Economy and Labour of 1 July 2004.

8. and the websites of the Ministry of Agriculture and Rural Development and the Ministry of Regional Development 